\title{
Euroscepticism as an Instrument of Foreign Policy
}

\section{SHARON PARDO ${ }^{\mathrm{a}} \&$ NEVE GORDON $^{\mathrm{ab}}$}

${ }^{a}$ Ben-Gurion University of the Negev, Beer Sheva, Israel

${ }^{\mathrm{b}}$ Queen Mary University of London, London, UK

\begin{abstract}
This article advances three arguments about Euroscepticism. First, using Israel as a case study we describe its alliances with Eurosceptic political actors, claiming that while each side hopes to benefit from these alliances to advance particular interests, the attraction among the actors are based on ideological affinities that do not align with the norms informing EU policies. If these norms become more contested, it may make it more difficult to construct a 'normative power' based approach in EU foreign policy. Second, we reveal how third parties can use Euroscepticism as an instrument for shaping EU foreign policy. Finally, we expose how this strategy produces a political paradox. By allowing itself to become an instrument deployed by a third party, the Eurosceptic member state also agrees to be pushed back into the fold of the EU apparatus, thus reconstituting itself as an internal actor, one which has stakes in the process and is willing to play by the rules of the game.
\end{abstract}

KEYWORDS: EU Foreign Affairs Council; EU-Israeli relations; Euroscepticism; Greece; Normative Power Europe; Populist radical right parties; Syriza.

In January 2016, the European Union's (EU) Foreign Affairs Council (FAC) reinforced its 'differentiation policy' in the 'conclusions on the Middle East Peace Process' (MEPP). It highlighted the EU's position that products from Israeli settlements in the Occupied Palestinian Territories must be labeled clearly in all the 28 member states (MS), and expressed the EU's commitment to ensure that 'all agreements between [...] Israel and the EU must unequivocally and explicitly indicate their inapplicability to the territories 
occupied by Israel in 1967. ${ }^{1}$ While several MS hailed the FAC's conclusions, in the days leading up to the vote, the foreign policy document constantly was changed, and its criticism of Israel's colonial project was softened.

The drama behind the scenes cannot be found in the FAC's official records, but its traces appear in internal draft proposals leaked to the authors. ${ }^{2}$ These drafts underscore the increasing importance of a relatively new tool deployed to shape EU foreign policy: Namely, the use of Euroscepticism by third parties as an instrument for modifying EU foreign policy. While the leaked internal draft proposals reveal how the FAC Conclusions were changed, interviews carried out with senior European and Israeli officials suggest that Israel in effect was the '29 ${ }^{\text {th }}$ delegation' in the EU's negotiation room in Brussels, 'reading EU draft texts and amendments in real time. ${ }^{3}$ More importantly, these senior officials propose that Israel successfully exploited Greece's dissatisfaction with European austerity policies to advance its own political goals.

Correspondence Address: Sharon Pardo, Department of Politics and Government, Ben-Gurion Universityof the Negev, P.O. Box 653, Beer Sheva 8410501, Israel; E-mail: pardos@bgu.ac.il. Neve Gordon, Department of Politics and Government, Ben-Gurion University of the Negev, P.O. Box 653, Beer Sheva, 8410501, Israel \& School of Law, Queen Mary University of London, Mile End Road, London, E1 4NS, UK; E-mail: ngordon@bgu.ac.il; neve.gordon@qmul.ac.uk.

${ }^{1}$ Council of the EU (2016) Press Release: Council Conclusions on the MEPP, January

18, Clause 8, available at: http://www.consilium.europa.eu/en/press/pressreleases/2016/01/18/fac-conclusions-mepp, accessed July 17, 2018.

${ }^{2}$ Five internal draft proposals were leaked to the authors in February 2016.

${ }^{3}$ Andrew Rettman (2016) Israel Got Real-Time Leaks from EU Security Talks, euobserver, February 8, available at: https://euobserver.com/investigations/132166, accessed July 17, 2018. 
Using Israel as a case study, in this article we advance three arguments about Euroscepticism. First, we describe the alliances Israel is creating with Eurosceptic actors, claiming that while each side hopes to benefit from these alliances to advance particular interests, the attraction among the different actors are based on ideological affinities that do not sit well with some of the dominant norms informing EU policies. In some instances, these alliances aim to weaken 'Normative Power Europe's' core norms, ${ }^{4}$ while on other occasions they may strive to undermine norms informed by the neoliberal consensus. ${ }^{5}$ Insofar as these norms are contested within the EU, it makes it more difficult to construct a 'normative power' based approach in both EU internal and foreign policy.

Second, we reveal how third parties can use Euroscepticism as an instrument for shaping foreign policy, showing how Israel exploited the Eurosceptic proclivities of a MS to alter the FAC conclusions. Finally, we expose how this strategy produces a political paradox. By allowing itself to become an instrument deployed by a third party, the Eurosceptic MS also agrees to be pushed back into the fold of the EU apparatus, thus reconstituting itself as an internal actor which has stakes in the process and is willing to play by the rules of the game. In a sense, the instrumentalization of Euroscepticism by third parties ultimately may soften the Eurosceptic stance.

\footnotetext{
${ }^{4}$ See article by Ian Manners in this special issue; see also Ian Manners (2002) Normative Power Europe: A Contradiction in Terms?, Journal of Common Market Studies, 40(2), pp. 235-258.

${ }^{5}$ Wendy Brown (2015) Undoing the Demos: Neoliberalism's Stealth Revolution (Cambridge: MIT Press).
} 


\section{Euroscepticism}

In their seminal research on the sources of Euroscepticism, Liesbet Hooghe and Gary Marks explain that the term 'expresses doubt or disbelief in Europe and European integration in general. ${ }^{6}$ Accordingly, we refer to Euroscepticism as the distrust and opposition to the process of European integration, ${ }^{7}$ including negative attitudes toward the EU's declared principles, norms, values, policies, bodies and institutions.

Paul Taggart and Aleks Szczerbiak distinguish between 'hard' and 'soft' Euroscepticism. Hard Euroscepticism 'implies outright rejection of the entire project of European political and economic integration, and opposition to one's country joining or remaining a member of the EU.' In practice, 'hard Euroscepticism' 'is expressed by a principled objection to the current form of integration in the EU on the grounds that it

offends deeply held values or, more likely, is the embodiment of negative values. ${ }^{8}$ By

\footnotetext{
${ }^{6}$ Liesbet Hooghe \& Gary Marks (2007) Sources of Euroscepticism, Acta Politica, 42(23), p. 120.

${ }^{7}$ Paul Taggart (1998) A Touchstone of Dissent: Euroscepticism in Contemporary Western European Party Systems, European Journal of Political Research, 33(3), pp. 363-388; Hajo G. Boomgaarden \& André Freire (2015) Religion and Euroscepticism: Direct, Indirect or No Effects? West European Politics, 32(6), pp. 1240-1265.

${ }^{8}$ Paul Taggart \& Aleks Szczerbiak (2004) Contemporary Euroscepticism in the Systems of the European Union Candidate States of Central and Eastern Europe, European Journal of Political Research, 43(1), p. 3; see also Petr Kopecký \& Cas Mudde (2002)
} 
contrast, soft Euroscepticism 'involves contingent or qualified opposition to European integration. It may take the form of 'policy' Euroscepticism or 'national-interest' Euroscepticism, although these often overlap. ${ }^{9}$ In both cases, Euroscepticism is driven by ideological and strategic motivations.

Building on insights informing the existing literature, in the following pages we add another crucial layer to the study of Euroscepticism. While we focus on Israel, Russia also has exploited the Euroscepticism of radical right parties in Europe to advance its interests over the past few years, ${ }^{10}$ but this and other similar cases have not been conceptualized as the exploitation of Euroscepticism as an instrument of foreign policy deployed by third parties. Israel's exploitation of Euroscepticism in order to sway EU foreign policy in a way that is conducive to its own objectives is, we maintain, a relatively new phenomenon and involves a paradoxical twist since the Eurosceptic MS that intercedes at the behest of a third party actually intervenes in the process through which a cohesive EU foreign policy is shaped and in this way reasserts its position within the European framework.

\section{Israel's Relations with Eurosceptic Actors}

The Two Sides of Euroscepticism: Party Positions on European Integration in East Central Europe, European Union Politics, 3(3), p. 300.

${ }^{9}$ Taggart, et al., ‘Contemporary Euroscepticism', p. 40.

${ }^{10}$ See for example, Antonis Klapsis (2015) An Unholy Alliance: The European Far Right and Putin's Russia (Brussels: WMCES). 
EU-Israeli relations have received considerable scholarly attention in recent years. ${ }^{11}$

While there is no Israeli grand strategy towards the EU, Israel has exploited differences among MS in order to try to influence the Union's foreign policy in a way that accords with its own interests. Already in 1980, for example, just before the European Community (EC) launched its own peace initiative with the Venice Declaration, Israel tried to take advantage of disagreements among the Community's members in order to influence the precise formulation of how Europe envisions the resolution of the Middle East conflict. ${ }^{12}$ Similarly, in 2004, immediately after the International Court of Justice

${ }^{11}$ See for example, Sharon Pardo (2013) The Year that Israel Considered Joining the European Economic Community, Journal of Common Market Studies 51(5), pp. 901915; Neve Gordon \& Sharon Pardo (2015) Normative Power Europe and the Power of the Local, Journal of Common Market Studies 53(2), pp. 416-427; Patrick Müller \& Peter Slominski (2017) The Role of Law in EU Foreign Policy-Making: Legal Integrity, Legal Spillover, and the EU Policy of Differentiation Towards Israel, Journal of Common Market Studies 55(4), pp. 871-888; Krassimir Y. Nikolov (2017) Partnership after Peace? An Optimistic view on the EU's Future Special Privileged Relations with the States of Israel and Palestine, Diplomacy 19, pp. 228-267; Anders Persson (2017) Shaping Discourse and Setting Examples: Normative Power Europe can Work in the IsraeliPalestinian Conflict, Journal of Common Market Studies 55(6), pp. 1415-1431; Anders Persson (2018) 'EU Differentiation' as a Case of 'Normative Power Europe' (NPE) in the Israeli-Palestinian Conflict, Journal of European Integration, 40(2), pp. 193-208; Guy Harpaz (2018) The Front Polisario Verdict and the Gap Between the EU's Trade Treatment of Western Sahara and Its Treatment of the Occupied Palestinian Territories, Journal of World Trade, 52(4), pp. 619-642.

${ }^{12}$ Patrick Müller (2012) EU Foreign Policymaking and the Middle East Conflict. The Europeanization of National Foreign Policy (New York: Routledge). 
(ICJ) issued its advisory opinion that the Israeli separation barrier was a violation of international humanitarian and human rights law, ${ }^{13}$ and just before the United Nations General Assembly (UNGA) voted on the matter, Israel lobbied intensively trying to play MS one against the other in an effort to prevent the adoption of a resolution supporting the ruling. ${ }^{14}$

Israel's exploitation of Euroscepticism to advance its political interests is, however, a relatively new phenomenon. In recent years, Israel has established cordial relations with leaders and senior officials of Eurosceptic populist right-wing parties and governments. ${ }^{15}$ In 2015, Israel Ministry of Foreign Affairs (MFA) adopted 'Guidelines on

${ }^{13}$ International Court of Justice (2004) Legal Consequences of the Construction of a Wall in the Occupied Palestinian Territory, Advisory Opinion, ICJ Reports, No. 131, pp. 136203.

${ }^{14}$ Sharon Pardo \& Joel Peters (2010) Uneasy Neighbors: Israel and the European Union (Lanham: Lexington Books), pp. 7, 19.

${ }^{15}$ Noa Landau (2018) Splitting the EU: Israel's Tightening Alliance with Central Europe's Nationalist Leaders, Haaretz, July 8, available at https://www.haaretz.com/israel-news/.premium-splitting-the-eu-israel-s-tighteningalliance-with-central-europe-1.6247069, accessed July 17, 2018; Yehuda Ben-Hur Levy (2015) The Undiplomats: Right-Wing Populists and Their Foreign Policy, available at: http://www.cer.eu/sites/default/files/publications/attachments/pdf/2015/pb_ybl_undiplo_ 21aug15-11804.pdf, accessed July 17, 2018; see also, Cas Mudde (2007) Populist 
Communication with Radical Right Parties in Europe.' While the document remains classified, sources familiar with the document told us that the Guidelines stipulate three major conditions and considerations: i) the Israeli government is not allowed to communicate with anti-Semitic and neo-Nazi radical right parties, whose leaders and/or members call for the destruction of Israel and of the European Jewish communities; ii) the Israeli government will not launch a dialogue with a radical right party if the local Jewish community is against such a dialogue; iii) the Israeli government will consider the positions of 'like minded countries' toward the relevant radical right party. ${ }^{16}$ Nonetheless, Israeli politicians regularly meet with Eurosceptic leaders who express pro-Israeli sentiments, but have anti-Semitic tendencies. For instance, Israeli officials maintain strong relations with the Dutch right-wing populist Party for Freedom led by Geert Wilders, with the Hungarian Fidesz right-wing populist party led by Viktor Orbán, ${ }^{17}$ and

Radical Parties in Europe (Cambridge: Cambridge University Press); Cas Mudde (2017) On Extremism and Democracy in Europe (Oxon: Routledge).

${ }^{16}$ Authors Interview with a senior Israeli official, Tel Aviv, March 30, 2017.

${ }^{17}$ Paul Lendvai (2017) Orbán: Europe's New Strongman (Oxford: Oxford University Press), pp. 230, 243, 249; Anshel Pfeffer (2018) Orbán is Coming to Israel to Meet His Soulmate Netanyahu. Here's How He's Taking Down Hungary's Democracy, Haaretz, July 17, available at https://www.haaretz.com/worldnews/europe/.premium.MAGAZINE-how-orban-is-taking-down-hungary-s-democracy1.6280256, accessed July 17, 2018. 
with the Italian Lega Nord party. ${ }^{18}$ Cas Mudde is of the opinion that populist radical right parties across Europe 'increasingly look at Israel as a model, i.e., an "ethnocracy" which they want to (re-)instate in their own country.' Moreover, Mudde claims that these parties see in Israel's major right-wing governing party - the Likud - 'an ideological ally, in terms of ethnic nationalism in the overarching struggle against "Global Islam.". 19

Israel also nurtures relations with Eurosceptic governments. In fact, one of Israel's former top diplomats admitted to us that, 'for many years, and especially since the 2004 enlargement, Israel organized workshops, or as we called them "dialogues," with these countries on how the EU works and on how to block decisions within the EU apparatus.' According to the former diplomat, who personally participated in such workshops, and even organized some of them:

[W]hile Israel knows well that these Eurosceptic [MS] are not the most influential EU actors, still Jerusalem hopes that their growing influence will exert some pressure on other EU members and the Union institutions, especially with regards to the Israeli-Palestinian conflict. ${ }^{20}$

The attraction, it appears, is mutual, whereby Israel seeks out relations with these Eurosceptic forces due to certain ideological convergences that defy aspects of the EU's traditional self-identity and norms. ${ }^{21}$ In April 2016, for example, following an invitation

${ }^{18}$ Landau, 'Splitting the EU'.

${ }^{19}$ E-mail correspondence between the authors and Cas Mudde, March 19, 2017.

${ }^{20}$ Authors Interview with a former top Israeli diplomat, Tel Aviv, February 13, 2017.

${ }^{21}$ Authors Interview with a senior Israeli official, Jerusalem, 25 January 2016. 
by the Likud party, Heinz-Christian Strache, the leader of the Austrian FPÖ party, visited Israel. During his visit, he showed support for Israeli products from the Occupied Territories (OT). A leading Likud member said that the MFA policy of boycotting FPÖ party officials 'was wrong, because Strache is a friend of Israel.' Strache 'wants to learn about Israel and encourage Europeans to buy Israeli products. How long can we give a cold shoulder to people who want to show us love? ${ }^{22}$ The following year, Strache vowed to do all in his power, 'be it legislative or eventually executive, to move the [Austrian] Embassy [...] to Jerusalem. ${ }^{23}$

Israel understands that once the dominant EU norms become more contested, it will become more difficult to construct a 'normative power'-based approach toward Israel, mitigating some of the external European pressure to end its colonial project. Hence, Israeli relations with right-wing populist parties are based, on the one hand, on short term opportunistic calculations, whereby the European populist parties may use the relation with Israel to dispel, for example, their anti-Semitic / 'brown' image, while Israel

\footnotetext{
${ }^{22}$ Herb Keinon \& Reuters (2016) Peres Refuses to Meet with Leader of Far-Right Austrian Freedom Party, The Jerusalem Post, April 12, available at http://www.jpost.com/Israel-News/Politics-And-Diplomacy/Peres-refuses-to-meet-withleader-of-far-right-Austrian-Freedom-Party-450996, accessed July 17, 2018.

${ }^{23}$ Raphael Ahern (2017) In Austria, Rise of Pro-Israel, Far-Right Faction Forces Israel into Corner, The Times of Israel, October 11, available at: https://www.timesofisrael.com/in-austria-rise-of-pro-israel-far-right-faction-forces-israelinto-corner, accessed July 17, 2018.
} 
uses the Eurosceptic actor to advance specific interests either in their country's parliament or in EU institutions. On the other hand, the convergence among these actors may be based on deeper ideological affinities aimed at altering some of the core liberal norms associated with EU policies. Here we only can gesture toward such uses of Euroscepticism, while it is obvious that more research needs to be carried out to analyze properly the effects of such alliances.

It is vital, however, to stress that Israel's exploitation of Euroscepticism differs from its efforts to take advantage of the diverse national interests of MS in order to advance particular political or economic objectives. In the past, for example, Israel used the different economic interests of the MS in its campaign against the Union's 'REACH regulation,' which protects human health and the environment from the risks that can be posed by chemicals. ${ }^{24}$ While the exploitation of diverse interests among MS involves Israel's exploitation of conflicted positions on the matter at hand, the use of Euroscepticism as a third-party instrument exploits a MS's contingent, qualified or outright opposition to the process of European integration ${ }^{25}$ to advance an EU foreign policy that is unrelated to the grievances motivating the Eurosceptic stance.

\footnotetext{
${ }^{24}$ Ora Coren (2006) Haichud Hairopi Neged Teve: Al Yisrael Lishkol Mediniyuta Beinyan Trufot Generiot [The European Union against Teva: Israel must consider its policy regarding generic drugs], The Marker, November 28, available at: https://www.themarker.com/markets/1.388335, accessed July 17, 2018. ${ }^{25}$ Taggart, 'A Touchstone', p. 366.
} 
Israel's use of a MS's Euroscepticism to modify EU foreign policy is accordingly similar to its exploitation of guilt for the Holocaust or Islamophobia, in the sense that in such cases a specific political position is exploited to advance an unrelated topic. For example, in the 2007-2009 'upgrade process' of the EU-Israeli relationship, Israel took advantage of the German Presidency of the EU, using German Holocaust guilt to convince it to push the Union to reaffirm its determination to upgrade bilateral relations and to issue guidelines for strengthening the political dialogue structures with Israel (the so-called December 2008 'upgrade process'). ${ }^{26}$ Nonetheless, there is also a difference between these two strategies: the emphasis of Euroscepticism wittingly or not serves as a push back against certain norms that inform EU policy, while the invocation of Holocaust guilt, in and of itself, does not necessarily weaken such norms.

\section{Syriza's Euroscepticism}

Following the 2008 financial crisis, the economic breakdown in Greece, Europe's migration crisis and the Brexit referendum in the United Kingdom (UK), Eurosceptic attitudes within Europe have been on the rise. One of the parties that used its Eurosceptic message to garner widespread support was Syriza. From its first days in government, Syriza and its leaders have been committed to find a way out from what they perceive to be 'the humiliation' of the Greek people 'at the hands of the masters of the Eurozone and the EU. ${ }^{27}$ Prime Minister (PM) Alexis Tsipras himself supported the general perception

\footnotetext{
${ }^{26}$ Pardo, et al., Uneasy Neighbors, pp. 65-68.

${ }^{27}$ Kevin Ovenden (2015) Syriza: Inside the Labyrinth (London: Pluto Press), p. xvi.
} 
that during the negotiations over the austerity measures, 'we have lost our sovereignty'28 to Brussels, the Troika and Germany, while Foreign Minister (FM) Nikos Kotzias 'casts the EU as a potential enemy who wants to cheat us and look down on us. ${ }^{29}$ According to Kotzias, Greece has become a 'debt colony' within the EU. ${ }^{30}$ 'We will not raise our hands like students asking for permission,' the FM said, ${ }^{31}$ adding that the powerful EU countries, and especially Germany, are characterized by economic cultural nationalism

${ }^{28}$ Paul Mason (2015) The Inside Story of Syriza's Struggle to Save Greece, The Nation, December 18, p. 21, available at https://www.thenation.com/article/the-inside-story-ofsyrizas-struggle-to-save-greece, accessed July 17, 2018.

${ }^{29}$ Xenia Kounalaki (2015) Kotzias, Dugin and the EU, ekathimerini.com, January 29, available at: http://www.ekathimerini.com/166715/article/ekathimerini/comment/kotziasdugin-and-the-eu, accessed July 17, 2018.

${ }^{30}$ Nikos Kotzias (2013) Greece: Debt Colony (Athens: Patakis Publishers).

${ }^{31}$ Aristotle Tziampiris (2017) Foreign Policy Against Austerity: Syriza’s Multifaceted Experiment, in: Spyridon N. Litsas, Aristotle Tziampiris (eds) Foreign Policy Under Austerity: Greece's Return to Normality? (London: Palgrave Macmillan), pp. 261-292, 265. 
and racism. ${ }^{32}$ It was against this background that the Syriza government took a 'U-turn' in its position toward Israel. ${ }^{33}$

\section{Israeli-Greek rapprochement}

While Greece recognized Israel already in 1949, the relationship between the two countries was ambivalent, aloof, distant and uneasy, mainly because of traditional Greek anti-Americanism, the Greek dependence upon Arab oil, the Greek desire for Arab support in the United Nations (UN) on the Cyprus issue, and a political alliance between Greece and the Palestinians. According to Aristotle Tziampiris, it took 41 years (1990) before Greece finally raised its diplomatic relations with Jerusalem to ambassadorial level, although Israeli-Greek relations remained cool for an additional 19 years, and only in 2009 following an unprecedented flurry of diplomatic activities between Jerusalem and Athens did relations begin to improve substantially. ${ }^{34}$

During the 2012 and the 2015 elections campaigns, Syriza and its leadership were highly critical of the emergence of Israeli-Greek cooperation, and the party was well

\footnotetext{
${ }^{32}$ Kotzias, Greece, summary.

${ }^{33}$ Asa Winstanley (2015) Syriza's U-Turn on Israel is Now Complete, Middle East Monitor, November 28, available at: https://www.middleeastmonitor.com/20151128syrizas-u-turn-on-israel-is-now-complete/amp/, accessed July 17, 2018.

${ }^{34}$ Aristotle Tziampiris (2015) The Emergence of Israeli-Greek Cooperation (Cham: Springer).
} 
known for its pro-Palestinian positions. ${ }^{35}$ In 2011, for example, Tsipras was among the Greek activists who were scheduled to board a Gaza-bound flotilla aimed at breaking the Israeli siege of Gaza. Syriza's party platform called for the complete 'abolition of military cooperation with Israel,' and Greek 'support for [the] creation of a Palestinian state within the 1967 borders. ${ }^{36}$ After assuming office, however, Syriza's hostility toward Jerusalem began to change. By January 2016, Greece, under the leadership of PM Tzipras, held a trilateral summit in Nicosia with Israel and Cyprus, and officially agreed on 'closer cooperation and a coordinated set of policies' in the fields of 'energy, tourism, research and technology, environment, water management, combating terrorism and migration.'37 Each of the three allies has its own reasons for this regional 'quasi-alliance,' yet energy interests, animosity toward Turkey and the Eastern Orthodox Church's financial interests and properties in Israel are the three primary motivations that all the partners have in common. ${ }^{38}$ Tziampiris concludes that from a Greek perspective 'the emergence of Israeli-

35 Ibid.

${ }^{36}$ Syriza (2012) Greece: SYRIZA’s 40-Point Program, May 27, Clause 38, available at http://links.org.au/node/2888, accessed July 17, 2018.

${ }^{37}$ Israel MFA (2016) Trilateral Meeting Between Israel, Greece and Cyprus, January 28, available at http://mfa.gov.il/MFA/PressRoom/2016/Pages/Trilateral-meeting-betweenIsrael-Greece-and-Cyprus-28-Jan-2016.aspx, accessed July 17, 2018.

${ }^{38}$ Zenonas Tziarras (2016) Israel-Cyprus-Greece: A ‘Comfortable’ Quasi-Alliance, Mediterranean Politics 21(3), p. 407; Nir Hasson (2017) Greek Orthodox Church Quietly Selling Off Israeli Assets at Fire Sale Prices, Haaretz, October 14, available at 
Greek cooperation constitutes the most significant development and new direction in Greek foreign policy. ${ }^{39}$ Similarly, an Israeli top diplomat believes that 'the Israeli-Greek alliance is probably one of the most important foreign policy strategic assets that Israel successfully developed in the past years. It is also significant for Israeli-EU relations. ${ }^{40}$

The rapprochement between the two countries served as the condition of possibility for Israel's exploitation of Greek Euroscepticism to advance its own political objectives. Exploiting Greek anger toward the EU austerity policies, the Israeli MFA learned in mid-December 2015 that the FAC was about to adopt in its January 2016 meeting conclusions that would draw, yet again, a clear distinction between Israel-proper and the territories it occupied in 1967, thus legitimizing the implementation of sanctions on exports of Israeli products from the OT. Fearing that such a conclusion could bolster the much broader and more threatening Boycott, Divestment and Sanctions (BDS) campaign against Israel ${ }^{41}$ the Israeli government decided to try to modify the conclusions' wording, softening the critique against its colonial project and its violation of international law.

https://www.haaretz.com/israel-news/1.816980, accessed July 17, 2018; Authors Interview with a senior Israeli diplomat, Beer Sheva, November 21, 2017. ${ }^{39}$ Tziampiris, The Emergence, $\mathrm{p} 1$.

${ }^{40}$ Authors Interview with a senior Israeli diplomat, Tel Aviv, February 13, 2017.

${ }^{41}$ Barak Ravid (2016) New EU Draft Resolution Draws Stark Distinction Between Israel, Settlements, Haaretz, January 17, available at https://www.haaretz.com/israelnews/.premium-1.697683, accessed July 17, 2018. 
In early January 2016, the Israeli MFA began contacting those MS, which it thought would be willing to exert pressure on the EU to reword certain clauses in the FAC conclusions in such a way that they would lose their potency. Through the so-called 'Regional Group for Crisis Response, ${ }^{42}$ the 'Visegrad Four' $(\mathrm{V} 4)^{43}$ the EU Baltic MS, Germany, and the UK, Jerusalem collected first-hand information regarding the precise wording of the draft proposal. According to senior Israeli officials, ultimately Greece played a vital role in convincing the other EU MS to soften the Conclusion's language. ${ }^{44}$

The first draft text of the FAC conclusions, which was circulated among EU MS on 11 or 12 January 2016, included clauses whose wording Israel found extremely troublesome. Israel approached Greece, a candidate that just several years earlier would have been unwilling to cooperate, exploiting, on the one hand, the newly devised energy and security alliance among Israel, Greece and Cyprus as well as Israel's and Greece's fraught relations with Turkey ${ }^{45}$ and, on the other hand, Greece's Euroscepticism

${ }^{42}$ The MS of this regional group are Bulgaria, Cyprus, Greece and Romania. The group aims at boosting the partnership between its members in cases of common security and migratory challenges.

${ }^{43}$ These are the Czech Republic, Hungary, Poland and Slovakia.

${ }^{44}$ Authors Interview with a senior Israeli diplomat, Brussels, June 7, 2017.

${ }^{45}$ Following the discovery of offshore natural gas by Israel and Cyprus, Greece discussed with the two countries the idea of becoming alternative European energy providers, with Greece being the transit state for their gas. In March 2014, however, it was found that the 'financial and topographic realities render such a pipeline financially and topographically 
informed by its aversion toward EU austerity policies. According to Israeli and Greek officials who we interviewed, it was Greece's opposition toward EU austerity programs and animosity toward Germany even more than the fledgling strategic partnership between Greece and Israel that motivated Greece to lobby for the modification of FAC's conclusions. ${ }^{46}$ Some interviewees suggested that Greece used the occasion as a form of symbolic reprisal, channeling its animosity toward the EU and Germany for compelling it to make drastic cuts in public spending. ${ }^{47}$ As one Israeli official put it: 'We do our utmost to make sure that the Eurosceptic countries - and in the past year mainly Greece - fight on any possible issue with other EU members, so that the Union heads for a crashlanding. ${ }^{48}$ Another former Israeli senior diplomat admitted that 'the issue is not to find Eurosceptic [MS]. We always have the Czech Republic, Hungary, Poland and others. The

infeasible'; see further Allison Good (2014) A False Hope: Eastern Mediterranean Gas Through Greece and Cyprus, The National Interest, June 2, available at http://nationalinterest.org/feature/false-hope-eastern-mediterranean-gas-through-greececyprus-10577, accessed July 17, 2018.

${ }^{46}$ Authors Interview with senior Israeli and Greek diplomats, Brussels, June 7, 2017; Beer Sheva, November 21, 2017.

${ }^{47}$ Ibid.

${ }^{48}$ Authors Interview with a senior Israeli official, Jerusalem, January 25, 2016. 
challenge is to convince a Eurosceptic EU member to operate with the same passion of Greece and block the Union's voting machinery. ${ }^{49}$

Within a span of a single week, the FAC's proposed document went through five drafts, and each draft was sent by the Greek officials in both Athens and Brussels to the MFA in Brussels and Jerusalem, where Israeli officials introduced changes to the wording, sending the document back to the Greeks, who then proposed these changes to the relevant EU officials, as well as to the members of the FAC. The objective was to frame Israel's colonial project as a symmetric conflict between two parties, which ultimately would soften the critique of international law violations, while also deflecting the Palestinian call for BDS. In what follows, we examine differences between the first draft and final document, to underscore some of the changes.

\section{The January 2016 FAC Conclusions}

One kind of change involves limiting Israel's liability by downplaying the extent of violations it has carried out in the Palestinian territories. The changes introduced in the last sentence of the first clause exemplify this type of modification. The first draft ends with the following sentence: 'The EU recalls the special significance of the holy sites and calls for upholding the status quo in line with previous understandings and with respect to

\footnotetext{
${ }^{49}$ Authors Interview with a former senior Israeli diplomat, Beer Sheva, November 21, 2017. See also, Landau, 'Splitting the EU'.
} 
Jordan's special role. ${ }^{50}$ The final document adds an important qualification. It reads as follows: 'The EU recalls the special significance of the holy sites, and calls for upholding the status quo put in place in 1967 for the Temple Mount / al-Haram al-Sharif in line with previous understandings and with respect to Jordan's special role. ${ }^{51}$ Hence, in the final document the EU emphasizes the significance of maintaining the status quo only in Temple Mount / al-Haram al-Sharif and not in other holy sites or in Jerusalem and the West Bank more generally. This is crucial considering that Israel continuously is changing the 'status quo put in place in 1967' and by so doing is violating, inter alia, the Fourth Geneva Convention. ${ }^{52}$

Another type of change strives to frame the relations between the colonizer and the colonized as having a symmetrical component. An example of this kind of reframing can be found in Clause Ten of the final document:

The EU calls for all parties to take swift steps to produce a fundamental change to the political, security and economic situation in the Gaza Strip, including the end of the closure and a full opening of the crossing points, while addressing Israel's legitimate security concerns. Recent rocket fire by militant groups is unacceptable and underlines again the danger of escalation. All stakeholders must commit to non-violence and peace. [...] The EU calls all parties, state and

\footnotetext{
${ }^{50}$ Secretariat Mashreq/Maghreb (2016) Draft Council Conclusions - Middle East Peace Process - FAC 18 January 2016, Doc. 1/16 - Rev 1, 12 (?) January, Clause 1.

${ }^{51}$ Council of the EU, 'Press Release', Clause 1.

${ }^{52}$ Neve Gordon (2008) Israel's Occupation (California: University of California Press).
} 
non-state actors to guarantee unimpeded humanitarian access to Gaza, as foreseen by international humanitarian law, for national, local and international humanitarian organizations, including EU bodies and $[\mathrm{MS}] .^{53}$

Note that the clause is directed to 'all parties' as if they all bear the same responsibility for dismantling the colonial project. The clause then compares Israel's harsh military siege on Gaza and the economic crisis experienced by the Palestinians with Israel's 'legitimate security concerns.' The corresponding clause in the first draft also introduced a certain degree of symmetry, but it did not mention Israel's legitimate security concerns, the rocket fire by Palestinian militant groups, nor did it make symmetrical demands from 'all stakeholders. ${ }^{54}$

The symmetric valance of Clause Ten might be connected to the reformulation of Clause Seven in the final document, where the EU underscores in unequivocal terms the illegality of Israel's settlement project and in this sense is clearer than the original draft. The effort to produce an imagined symmetry between Israel and Palestine may have been motivated by a desire to create an illusory balance among the different clauses. What is important from our perspective is that neither symmetry nor balance adequately reflect the power differential between the two sides in the conflict, and that Greece intervened in order to introduce an illusionary symmetry at Israel's behest.

\footnotetext{
${ }^{53}$ Council of the EU, 'Press Release', Clause 10.

${ }^{54}$ Secretariat Mashreq/Maghreb, 'Draft', Clause 7.
} 
The most important change, however, involves Clause Six in the first draft and the corresponding Clause Eight in the final version, since this is the clause that has the potential to become operational. Clause Six in the first draft provided that:

The EU is united in its commitment to ensure consistent, full and effective implementation of existing [EU] legislation and bilateral arrangements applicable to settlement products. The EU will continue to unequivocally and explicitly make the distinction between Israel and those territories occupied by Israel in 1967, namely the Golan Heights, the West Bank including East Jerusalem, and the Gaza Strip. Since it does not consider them to be part of Israel's territory, the [EU] and its [MS] reiterate their commitment to ensure that all agreements of the EU and its [MS] with the State of Israel, in form and implementation, are not applicable to these territories. The Council reaffirms that this consistent position is fully in line with international law and should not in any way be equated to boycott, which the EU opposes. ${ }^{55}$

While the officials at the European External Action Service (EEAS) fully supported the wording of Clause Six of the first draft text, ${ }^{56}$ Israel perceived it to be extremely 'hostile' and 'unilateral. ${ }^{57}$ Through the Greek delegates, Israel tried to secure major changes to the text and a stronger condemnation of any sort of a boycott against Israel.

\footnotetext{
${ }^{55}$ Secretariat Mashreq/Maghreb, 'Draft', Clause 6.

${ }^{56}$ Authors Interview with senior EEAS official, Brussels, June 29, 2016.

${ }^{57}$ Authors Interviews with senior Israeli officials, Jerusalem and Brussels, January 25, 2016 and June 29, 2016.
} 
And, indeed in line with some of the Israeli wishes, and against the will of the EEAS officials, the wording of Clause Six was softened already in the second draft text and in the ones that followed.

Using the 'simplified written procedure,' the fifth draft text was approved by all the 28 MS ambassadors to the Political and Security Committee (PSC) on Friday 15 January 2016. Greece, however, had a change of heart. Within minutes after its Permanent Representative to the EU, agreed to the adoption of the fifth draft text using the silence procedure, he suddenly announced that Athens objects to the text's wording. According to one observer, 'the anger in the meeting room was palpable. ${ }^{58}$

After Greece expressed its dissatisfaction, it was agreed to form an informal working group to work on a sixth draft text, and which would be presented to the ministers and discussed by them during the FAC meeting the following Monday. Before the weekend, Greece was almost alone in its opposition to the fifth draft text, but on Monday morning it already enjoyed the full backing of the three other member countries of the 'Regional Group for Crisis Response' and of all the V4 countries. The final version of Clause Eight reads as follows:

The EU and its Member States are committed to ensure continued, full and effective implementation of existing EU legislation and bilateral arrangements applicable to settlements products. The EU expresses its commitment to ensure that - in line with international law-all agreements

${ }^{58}$ Authors Interviews with senior EEAS and Greek officials and diplomats, Brussels, June 29, 2016 and June 7, 2017. 
between the State of Israel and the EU must unequivocally and explicitly indicate their inapplicability to the territories occupied by Israel in 1967. This does not constitute a boycott of Israel, which the EU strongly opposes. ${ }^{59}$

In addition to emphasizing the strong opposition to a boycott (which already was introduced in previous drafts), the final formulation introduces an important change by erasing the following words: 'The EU will continue [sic] to unequivocally and explicitly make the distinction between Israel and those territories occupied by Israel in 1967, by ensuring inter alia the non-applicability of all EU agreements with the State of Israel, in the form of implementation, to these territories. ${ }^{60}$ By underscoring the distinction between Israel and the OT, this deleted sentence provides the reason why the agreements between Israel and the EU are inapplicable to the OT, and maintains that the distinction will be sustained by ensuring the non-applicability of agreements in the future. In this way, it produces a circular logic: a distinction exists between the two territories and therefore the agreements signed with Israel are not applicable to the OT, and because the agreements are not applicable to the OT, a distinction exists between them. By erasing the reasoning behind the inapplicability of the agreements - namely, the legal distinction between the territories - the final document modifies the reference of international law. If in the previous drafts the EU's commitment to international law referred to both the legal distinction between the territories and the agreements it had signed with Israel, now it

\footnotetext{
${ }^{59}$ Council of the EU, 'Press Release', Clause 8.

${ }^{60}$ Secretariat Mashreq/Maghreb (2016) Draft Council Conclusions - Middle East Peace Process - FAC 18 January 2016, Doc. 1/16 - Rev 5, 15 January, Clause 8.
} 
refers only to the applicability of the agreements. While this might appear to be a legal quibble, for Israel it was important and therefore Greece insisted on modifying the document.

According to one senior Israeli official, '[T]his was a triumph on so many fronts. At the national level, at the regional level and at the European level. We got the exact wording that we wanted. ${ }^{\prime 61}$ For the EU, this proactive Eurosceptic foreign policy instrument employed by Israel against the EU posed a new challenge, a challenge that Brussels still does not fully understand and recognize. In the words of one EEAS official: 'Months after the FAC meeting of January 2016, Brussels is still shocked and ashamed, licking its wounds, and trying to understand what exactly happened during that cold January. ${ }^{96}$

\section{Conclusion: The Paradox of Eurosceptic Intervention}

Israel and several other actors are using the Eurosceptic stance of certain EU MS as an opportunity to advance its own political goals. We pointed to three different yet interrelated processes. The first one, which still needs considerable empirical evidence to be analyzed properly, examines the alliances between right-wing Eurosceptic political actors, claiming that while each side hopes to benefit from these alliances in different ways, the attraction among the actors are based on ideological affinities aimed at altering the core liberal norms informing EU identity. If these core liberal norms become more

\footnotetext{
${ }^{61}$ Authors Interview with a senior Israeli official, Jerusalem, January 25, 2016.

${ }^{62}$ Authors Interview with an EEAS official, Herzliya, May 9, 2016.
} 
contested, it may make it more difficult to construct a 'normative power'-based approach in EU foreign policy, hence alleviating external pressures, in our case the ones directed against Israel.

The second process has to do with the use of Euroscepticism as an instrument for shaping foreign policy. In this case, Israel exploited the hardship of Greek austerity and its ensuing Eurosceptic stance, alongside a possible, even if economically unfeasible, energy deal, the deteriorating Turkish-Israeli relations and the Eastern Greek Orthodox Church's financial interests and properties in Israel in order to gain Greek support. Euroscepticism was, according to our informants, an important part of this equation and, accordingly, was transformed into an instrument that Israel wielded to achieve specific political objectives. Finally, we suggested that, by allowing itself to become a third party instrument, the Eurosceptic MS - in this case Greece - also agreed to be pushed back into the fold of the EU apparatus, thus reconstituting itself as an internal actor which has stakes in the process and is willing to play by the rules of the game.

In January 2015, it was FM Nikos Kotzias who warned that 'anyone who believes that because of the debt Greece will give up its sovereignty and its active participation in European politics is mistaken. ${ }^{63}$ Putting words into action, a year later, Athens proactively intervened in the conclusions formulated by FAC, even though it did not really have a direct stake in the document's precise wording. By encouraging this Eurosceptic MS to engage in the process Israel hoped to advance its own interests, but simultaneously this engagement helped produce unified European Conclusions on the

\footnotetext{
${ }^{63}$ Kounalaki, 'Kotzias, Dugin and the EU'
} 
MEPP,' which in effect softened the outsider perspective characterizing the Eurosceptic stance. That is, by taking on an active role in this saga, by insisting to influence the process, Greece actually moved a step back into the EU's fold.

\section{References}

Ahern, R. (2017) In Austria, Rise of Pro-Israel, Far-Right Faction Forces Israel into Corner. In: The Times of Israel, October 11. Available at: https://www.timesofisrael.com/in-austria-rise-of-pro-israel-far-right-faction-forces-israelinto-corner. Accessed July 17, 2018.

Ben-Hur Levy, Y. (2015) The Undiplomats: Right-Wing Populists and Their Foreign Policy. Available at: 
http://www.cer.eu/sites/default/files/publications/attachments/pdf/2015/pb_ybl_undiplo_ 21aug15-11804.pdf. Accessed July 17, 2018.

Boomgaarden, H.G. \& Freire, A. (2015) Religion and Euroscepticism: Direct, Indirect or No Effects? In: West European Politics, 32(6), pp. 1240-1265.

Brown, W. (2015) Undoing the Demos: Neoliberalism's Stealth Revolution (Cambridge: MIT Press).

Coren, O. (2006) Haichud Hairopi Neged Teve: Al Yisrael Lishkol Mediniyuta Beinyan Trufot Generiot [The European Union against Teva: Israel must consider its policy regarding generic drugs]. In: The Marker, November 28, Available at: https://www.themarker.com/markets/1.388335. Accessed July 17, 2018.

Council of the EU (2016) Press Release: Council Conclusions on the Middle East Peace Process, January 18. Available at: http://www.consilium.europa.eu/en/press/pressreleases/2016/01/18/fac-conclusions-mepp. Accessed July 17, 2018.

Good, A. (2014) A False Hope: Eastern Mediterranean Gas Through Greece and Cyprus. In: The National Interest, June 2. Available at: http://nationalinterest.org/feature/falsehope-eastern-mediterranean-gas-through-greece-cyprus-10577. Accessed July 17, 2018.

Gordon, N. \& Pardo, S. (2015) Normative Power Europe and the Power of the Local. In: Journal of Common Market Studies, 53(2), pp. 416-427.

Gordon, N. (2008) Israel's Occupation (California: University of California Press). 
Harpaz, G. (2018) The Front Polisario Verdict and the Gap Between the EU's Trade Treatment of Western Sahara and Its Treatment of the Occupied Palestinian Territories. In: Journal of World Trade, 52(4), pp. 619-642.

Hasson, N. (2017) Greek Orthodox Church Quietly Selling Off Israeli Assets at Fire Sale Prices. In: Haaretz, October 14. Available at: https://www.haaretz.com/israelnews/1.816980. Accessed July 17, 2018.

Hooghe, L. \& Marks, G. (2007) Sources of Euroscepticism. In: Acta Politica, 42(2-3), pp. 119-127.

International Court of Justice (2004) Legal Consequences of the Construction of a Wall in the Occupied Palestinian Territory, Advisory Opinion. In: ICJ Reports, No. 131, pp. 136-203.

Israel MFA (2016) Trilateral Meeting Between Israel, Greece and Cyprus, January 28. Available at: http://mfa.gov.il/MFA/PressRoom/2016/Pages/Trilateral-meeting-betweenIsrael-Greece-and-Cyprus-28-Jan-2016.aspx. Accessed July 17, 2018.

Keinon, H. \& Reuters (2016) Peres Refuses to Meet with Leader of Far-Right Austrian Freedom Party. In: The Jerusalem Post, April 12. Available at: http://www.jpost.com/Israel-News/Politics-And-Diplomacy/Peres-refuses-to-meet-withleader-of-far-right-Austrian-Freedom-Party-450996. Accessed July 17, 2018.

Klapsis, A. (2015) An Unholy Alliance: The European Far Right and Putin's Russia (Brussels: WMCES).

Kopecký, P. \& Mudde, C. (2002) The Two Sides of Euroscepticism: Party Positions on European Integration in East Central Europe. In: European Union Politics, 3(3), pp. 297 326. 
Kotzias, N. (2013) Greece: Debt Colony (Athens: Patakis Publishers).

Kounalaki, X. (2015) Kotzias, Dugin and the EU. In: ekathimerini.com, January 29. Available at:

http://www.ekathimerini.com/166715/article/ekathimerini/comment/kotzias-dugin-andthe-eu. Accessed July 17, 2018.

Landau, N. (2018) Splitting the EU: Israel's Tightening Alliance with Central Europe's Nationalist Leaders. In: Haaretz, July 8. Available at: https://www.haaretz.com/israelnews/.premium-splitting-the-eu-israel-s-tightening-alliance-with-central-europe1.6247069. Accessed July 17, 2018.

Lendvai, P. (2017) Orbán: Europe’s New Strongman (Oxford: Oxford University Press).

Manners, I. (2002) Normative Power Europe: A Contradiction in Terms? In: Journal of Common Market Studies, 40(2), pp. 235-258.

Mason, P. (2015) The Inside Story of Syriza's Struggle to Save Greece. In: The Nation, December 18. Available at: https://www.thenation.com/article/the-inside-story-ofsyrizas-struggle-to-save-greece. Accessed July 17, 2018.

Mudde, C. (2007) Populist Radical Parties in Europe (Cambridge: Cambridge University Press).

Mudde, C. (2017) On Extremism and Democracy in Europe (Oxon: Routledge).

Müller, P. (2012) EU Foreign Policymaking and the Middle East Conflict. The Europeanization of National Foreign Policy (New York: Routledge). 
Müller, P. \& Slominski, P. (2017) The Role of Law in EU Foreign Policy-Making: Legal Integrity, Legal Spillover, and the EU Policy of Differentiation Towards Israel. In: Journal of Common Market Studies, 55(4), pp. 871-888.

Nikolov, K.Y. (2017) Partnership After Peace? An Optimistic View on the EU's Future Special Privileged Relations with the States of Israel and Palestine. In: Diplomacy, 19, pp. 228-267.

Ovenden, K. (2015) Syriza: Inside the Labyrinth (London: Pluto Press).

Pardo, S. \& Peters, J. (2010) Uneasy Neighbors: Israel and the European Union (Lanham: Lexington Books).

Pardo, S. (2013) The Year that Israel Considered Joining the European Economic Community. In: Journal of Common Market Studies, 51(5), pp. 901-915.

Persson, A. (2017) Shaping Discourse and Setting Examples: Normative Power Europe Can Work in the Israeli-Palestinian Conflict. In: Journal of Common Market Studies, 55(6), pp. 1415-1431.

Persson, A. (2018) 'EU Differentiation' as a Case of 'Normative Power Europe' (NPE) in the Israeli-Palestinian Conflict. In: Journal of European Integration, 40(2), pp. 193-208.

Pfeffer, A. (2018) Orbán is Coming to Israel to Meet His Soulmate Netanyahu. Here's How He's Taking Down Hungary's Democracy. In Haaretz, July 17. Available at: https://www.haaretz.com/world-news/europe/.premium.MAGAZINE-how-orban-istaking-down-hungary-s-democracy-1.6280256. Accessed July 17, 2018.

Ravid, B. (2016) New EU Draft Resolution Draws Stark Distinction Between Israel, Settlements. In: Haaretz, January 17. Available at: https://www.haaretz.com/israelnews/.premium-1.697683. Accessed July 17, 2018. 
Rettman, A. (2016) Israel Got Real-Time Leaks from EU Security Talks. In: euobserver, February 8. Available at: https://euobserver.com/investigations/132166. Accessed July 17, 2018.

Secretariat Mashreq/Maghreb (2016) Draft Council Conclusions - Middle East Peace Process - FAC 18 January 2016, Doc. 1/16 - Rev 1, 12 (?) January.

Secretariat Mashreq/Maghreb (2016) Draft Council Conclusions - Middle East Peace Process - FAC 18 January 2016, Doc. 1/16 - Rev 5, 15 January.

Syriza (2012) Greece: SYRIZA’s 40-Point Program, May 27. Available at: http://links.org.au/node/2888. Accessed July 17, 2018.

Taggart, P. (1998) A Touchstone of Dissent: Euroscepticism in Contemporary Western European Party Systems. In: European Journal of Political Research, 33(3), pp. 363388.

Taggart, P. \& Szczerbiak, A. (2004) Contemporary Euroscepticism in the Systems of the European Union Candidate States of Central and Eastern Europe. In: European Journal of Political Research, 43(1), pp. 1-27.

Tziampiris, A. (2015) The Emergence of Israeli-Greek Cooperation (Cham: Springer).

Tziampiris, A. (2017) Foreign Policy Against Austerity: Syriza's Multifaceted Experiment. In: Litsas, S. N. \& Tziampiris, A. (eds) Foreign Policy Under Austerity: Greece's Return to Normality? (London: Palgrave Macmillan), pp. 261-292.

Tziarras, Z. (2016) Israel-Cyprus-Greece: A ‘Comfortable’ Quasi-Alliance. In: Mediterranean Politics, 21(3), pp. 407-427. 
Winstanley, A. (2015) Syriza's U-Turn on Israel is Now Complete. In: Middle East Monitor, November 28, Available at: https://www.middleeastmonitor.com/20151128syrizas-u-turn-on-israel-is-now-complete/amp/. Accessed July 17, 2018. 